\title{
The Use of by-product Coal as Fuel on Boiler Plants of Small and Medium Power
}

\author{
Murko Vasily Ivanovich \\ Mining institute \\ FSBEI "KuzSTU", Russia \\ Kemerovo, Russia \\ sib_eco@mail.ru
}

\author{
Hyamyalyainen Veniamin Anatolievich \\ Mining institute \\ FSBEI "KuzSTU", Russia \\ Kemerovo, Russia
}

\author{
Baranova Marina Petrovna \\ Institute of Engineering Systems and \\ Energy \\ FSBEI "Krasnoyarsk SAU" \\ Krasnoyarsk, Russia \\ marina60@mail.ru
}

\begin{abstract}
A significant environmental problem for the coal regions of Russia is the presence of large volumes of finedispersed coal sludges formed during the operation of coal mines and coal-preparation plants. In addition to direct environmental damage, storage of these sludges in sedimentation tanks, hydro-dumps or on sludge sites requires significant economic costs. Thus, the solution of the utilization problem of coal-enrichment wastes, especially finely-dispersed, represented by filter cakes of filtration compartments, containing practically all chemical reagents used in coal washing (flocculants, coagulants, etc.) is topical. The paper presents the results of research on the use of fine coalenrichment wastes as a fuel in boiler plants. It is shown that on the basis of these wastes it is possible to prepare a suspension water-coal fuel with a solid phase content of 56-60\%, with the required structural-rheological characteristics and a net calorific value of up to $13 \mathrm{MJ} / \mathrm{kg}$. A boiler with a thermal capacity of $0.63 \mathrm{MW}$ with a vortex combustion system efficiently operating on fuel from coal waste was designed, manufactured and tested. The composition and effect of plasticizing additives on the rheological characteristics of the fuel is defined; the dependence of fuel consumption on its ash content is established. The results of the boiler operation on this fuel showed its high efficiency (the efficiency is $\mathbf{8 3 - 8 5 \%}$ ) with the level of harmful emissions in the flue gas significantly below the permissible values.
\end{abstract}

Keywords - utilization of coal prepared waste, filter-cake, preparing, combustion of suspension coal-water fuel, structural and rheological characteristics

\section{INTRODUCTION}

A significant environmental problem for the coal regions of Russia is the availability of large volumes of finelydispersed sludge formed during the operation of coal mines and coal-preparation plants. In fact, around each mine or coal-preparation plant there are large areas occupied by these sludge in the form of sedimentation tanks, hydrodumps or sludge sites. It should be noted that these products contain most of all chemical reagents used in the process of coal enrichment (flocculants, coagulants, etc.). In addition to direct environmental damage (surface contamination of soil, water runoff, dust storms, etc.), the operation of such facilities requires significant economic costs. In many countries of the world (USA, France, China, etc.) this problem is solved by using these coal sludge as the main or additional fuel for nearby Coal-Fired Power Plants (CFPP) [1-8]. At the same time burning of coal sludge, which is, as a rule, substantially ballasted with water and ash fuel, is usually produced in boiling-bed boilers in the form of a coal-water slurry or coal paste. This energy use of energy sludge or fine-dispersed waste of coal-enrichment (FDWCE) is economically expedient only if they are located near the CFPP (within a radius of no more than $40-50 \mathrm{~km}$ ). These conditions cannot always be met. In this case, for the effective use of the FDWCE as the basis for fuel, the construction of a mini-CPP is required, which entails significant capital costs and organizational problems. The paper considers the possibility of using FDWCE as a fuel in boiler plants of small and medium power, which in an amount of at least 10 pieces are located within a radius of $40-50 \mathrm{~km}$ from the places of extraction and processing of raw materials. For the implementation of this facility, the technology and equipment for the preparation of suspended water-coal fuel (WCF) based on the FDWCE of Kuzbass coal-preparation plants (CPP) have been developed and experimentally investigated. At the same time, a hot-water boiler with a thermal capacity of $0.5(0.63) \mathrm{Gcal} / \mathrm{hr}(\mathrm{MGW})$ operating at the WCF was designed and manufactured [115].

The purpose of this consisted in establishment of possibility of using the coal waste as a power fuel.

\section{RAW MATERIALS AND TECHNIQUe OF PREPARATION OF CWS}

For the preparation of suspended water-coal fuel, representative samples of fine-dispersed waste of coal enrichment - filter cakes from the filtration departments of the CPP: coal pit "Komsomolets" and "named after S.M. Kirov" (Leninsk-Kuznetsk city, Kemerovo region). The characteristics of the FDWCE are presented in Table 1.

TABLE I. The Qualitative Characteristic Of The Filter CAKE

\begin{tabular}{|l|c|c|}
\hline \multicolumn{1}{|c|}{ Indicator name } & \multicolumn{2}{|c|}{ Numeric value } \\
\cline { 2 - 3 } & $\begin{array}{c}\text { CPP «Coal pit } \\
\text { «Komsomolet } \\
\text { s» }\end{array}$ & $\begin{array}{c}\text { «PP } \\
\text { named after } \\
\text { S.M. Kirov» }\end{array}$ \\
\hline Humidity, $\mathrm{W}_{\mathrm{t}}^{\mathrm{r}}, \%$ & 34,8 & 40,8 \\
\hline $\begin{array}{l}\text { Ash content (on dry condition of fuel), } \\
\mathrm{A}^{\mathrm{d}} \%\end{array}$ & 26,8 & 48,4 \\
\hline $\begin{array}{l}\text { The yield of volatile substances (on } \\
\text { the dry ashless state of the fuel), } \\
\mathrm{V}^{\text {daf }} \%\end{array}$ & 43,1 & 41,4 \\
\hline
\end{tabular}




\begin{tabular}{|c|c|c|}
\hline \multirow[b]{2}{*}{ Indicator name } & \multicolumn{2}{|c|}{ Numeric value } \\
\hline & $\begin{array}{c}\text { CPP } \ll \text { Coal pit } \\
\text { «Komsomolet } \\
s »\end{array}$ & $\begin{array}{c}\text { «CPP } \\
\text { named after } \\
\text { S.M. Kirov» }\end{array}$ \\
\hline $\begin{array}{l}\text { Sulfur total } \\
\text { (on a dry condition of fuel), } \mathrm{S}_{\mathrm{t}}^{\mathrm{d}}, \%\end{array}$ & 0,48 & 0,13 \\
\hline $\begin{array}{l}\text { The highest heat of combustion (on a } \\
\text { dry condition of fuel), } \mathrm{Q}_{\mathrm{s}}{ }^{\mathrm{daf}}, \mathrm{MJ} / \mathrm{kg}\end{array}$ & 33,04 & 33,00 \\
\hline $\begin{array}{l}\text { The lowest heat of combustion of the } \\
\text { working fuel, } \mathrm{Q}_{\mathrm{t}}^{\mathrm{r}}, \mathrm{MJ}\end{array}$ & 14,3 & 8,7 \\
\hline $\begin{array}{c}\text { Grain-size classification, } \mathrm{mm}, \% \\
0,250-3,0: \\
0,071-0,250 \\
\text { In total }\end{array}$ & $\begin{array}{c}8,4 \\
18,7 \\
72,9 \\
100,0\end{array}$ & $\begin{array}{c}6,3 \\
17,3 \\
76,4 \\
100,0\end{array}$ \\
\hline
\end{tabular}

The data in Table 1 show that the cake samples differ significantly in moisture content (34.8 and 40.8\%), ash content (26.8 and $48.4 \%)$ and, respectively, lower heat of combustion (14.3 and $8.7 \mathrm{MJ} / \mathrm{kg}$ ).

During the research from the mix of filter-cake and water solution of reagent-plastificator, the sample of suspension coal fuel was prepared on grinding chamber of the universal vibration stand.

During the research, samples of suspended coal fuel in an SVI grinding chamber were prepared from a mixture of filter cake and an aqueous solution of the plasticizer reagent. The amount of water and the content of the plasticizer in it were determined by calculation, depending on the quality of the starting product.

The received WCF samples were analyzed on a mass fraction of solid phase, granulometric structure, viscosity and stability by the standart methods.

Static stability was determined by the presence of sediment and water separation during storage of the sample under static conditions. The mass fraction of the solid phase was determined by the standard drying method in accordance with GOST 27314-91, the gran-size classification by wet sieving in accordance with GOST 2093-82. The lowest heat of combustion was determined by calculation in accordance with GOST 27313-87 [3-8].

To reduce the viscosity of the water coal suspension, a chemical composition of the plasticizing additive was developed, which is a product of thermal dehydration of monosodium phosphate or phosphoric acid.

The most effective amount of the additive was found, which was $0.25 \%$ of the solid phase content in the fuel.

\section{A. Preparation of pilot lots of WCF based on the FDWCE}

As the work is of applied importance, all the experiments were as close as possible to the industrial conditions.

Pilot lots of WCF based on the FDWCE were prepared at the coal preparation section of the experimental stand. Figure 1 shows the technological scheme for the preparation of WCF.

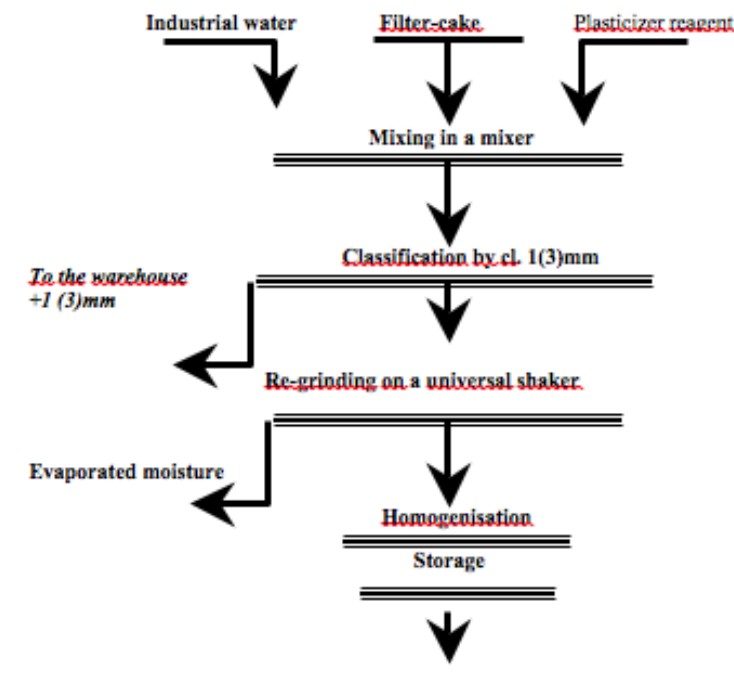

Fig. 1. Flow diagram of WCF preparation from filter cake.

According to the flow diagram, the initial filter cake and the aqueous solution of the plasticizer reagent were fed into a batch mixer, then the resulting water-coal suspension was dosed to a universal shaker, where there was further grinding and further mixing of the obtained fuel. The universal vibroinstallation is a bicameral vibratory mill consisting of concentrically arranged cylindrical chambers, loaded with balls and interconnected by channels. The initial suspension enters the inner chamber of the vibratory mill, moves downward and through the channels enters the outer chamber. In the outer chamber, the suspension moves upward. Unloading of the crushed material is carried out through the external threshold of the outer chamber. This principle of operation of the vibratory mill makes it possible to provide low energy costs for grinding the particles in the mixture at the required size of large particles in the finished fuel. The prepared WCF was pumped into storage tanks.

Table 2 shows the structural-rheological and thermophysical parameters of the pilot lots of WCF.

TABle II. Characteristics Of The Prepared Pilot lots OF WCF

\begin{tabular}{|c|c|c|c|c|c|}
\hline $\begin{array}{c}\text { Ash } \\
\text { content } \\
A^{d}, \%\end{array}$ & $\begin{array}{c}\text { Class } \\
\text { output is } \\
\text { more } \\
0,25 \mathrm{~mm} \text {, } \\
\%\end{array}$ & $\begin{array}{c}\text { Mass } \\
\text { content } \\
\text { of solid } \\
\text { phase, } \\
C_{\mathrm{T}}, \%\end{array}$ & $\begin{array}{c}\text { Effective } \\
\text { viscosity } \\
\text { at shear } \\
\text { rate } \\
81 \mathrm{c}^{-1}, \eta, \\
\mathrm{mPa} \cdot \mathrm{s}\end{array}$ & $\begin{array}{l}\text { Stab } \\
\text { ility, } \\
\text { day }\end{array}$ & $\begin{array}{c}\text { The lowest } \\
\text { heat of } \\
\text { combustion , } \\
Q_{i}^{r}, \mathrm{MJ} / \mathrm{kg}\end{array}$ \\
\hline \multicolumn{6}{|c|}{ Filter-cake CPP coal pit «Komsomolets» } \\
\hline 26,8 & 1,9 & 56,9 & 178 & 15 & 12,22 \\
\hline \multicolumn{6}{|c|}{ Filter-cake CPP coal pit «named after S.M. Kirov» } \\
\hline 48,4 & 1,4 & 56,6 & 148 & 15 & 8,24 \\
\hline
\end{tabular}

It was experimentally established that the productivity of a universal installation for the initial suspension varies in the range $0.155 \mathrm{t} / \mathrm{h}-0.217 \mathrm{t} / \mathrm{h}$, depending on the particle size in the initial suspension. In this mode of operation, the output of the class $+0.250 \mathrm{~mm}$ in the finished suspension did not exceed the limit $(\mathrm{R} 250 \leq 5 \%)$ required by the combustion conditions and was $1.4 \%-1.9 \%$. 


\section{WCF BURNING AT THE EXPERIMENTAL STAND}

Combustion of pilot lots of WCF was carried out on a boiler plant consisting of a boiler with a thermal capacity of $0.58 \mathrm{MW}$, a fuel supply system, an ash collecting system, a heat sink for heat removal, a draft equipment. The created boiler consists of a furnace - a vortex combustion chamber located in a water-cooled housing and an economizer for removing heat from hot flue gases formed in the furnace. The feed of WCF into the vortex furnace is carried out through a burner device with a pneumomechanical injector tangentially inner cylindrical surface of the combustion chamber [14-16]. Also, tangentially air is blown into the combustion chamber. Spray fuel is produced by compressed air, fed into the nozzle. The fuel supply is regulated by changing the engine speed of the fuel pump. The combustion chamber of the furnace is equipped with a water-cooled exaggeration, which allows to keep burning coal particles and sprayed WCF drops necessary time for their complete burn-out [16-20].

Dust collection system - two-stage, and consists of a block of battery cyclones and a fabric filter, which provides a high degree of cleaning of exhaust gases from dust. Table 3 shows the results of the combustion of pilot lots of WCF.

TABLE III. RESALTS OF COMBUSTION OF WCF

\begin{tabular}{|l|c|c|c|}
\hline & \multirow{2}{*}{$\begin{array}{c}\text { Measurem } \\
\text { ents unit }\end{array}$} & \multicolumn{2}{|c|}{ Numeric value for CPP coal pit } \\
\cline { 3 - 4 } & $\begin{array}{c}\text { «named after } \\
\text { S.M. Kirov» }\end{array}$ & «Komsomolets» \\
\hline $\begin{array}{l}\text { Heating } \\
\text { capacity of the } \\
\text { boiler }\end{array}$ & $\mathrm{MW}$ & $0,47-0,57$ & $0,52-0,66$ \\
\hline $\begin{array}{l}\text { Temperature } \\
\text { conditions in } \\
\text { the furnace }\end{array}$ & ${ }^{0} \mathrm{C}$ & $980-1050$ & $980-1050$ \\
\hline $\begin{array}{l}\text { Consumption } \\
\text { of WCF }\end{array}$ & $\mathrm{kg} / \mathrm{h}$ & $220-250$ & $170-210$ \\
\hline $\begin{array}{c}\text { WCF pressure } \\
\text { Pressure of } \\
\text { compressed air }\end{array}$ & $\mathrm{MPa}$ & 0,20 & 0,19 \\
\hline $\begin{array}{c}\text { Flue gas } \\
\text { temperature }\end{array}$ & ${ }^{\circ} \mathrm{C}$ & $250-260$ & $250-260$ \\
\hline $\begin{array}{c}\text { Efficiency } \\
\text { MPa }\end{array}$ & $\%$ & 0,83 & 0,85 \\
\hline
\end{tabular}

The figure shows the effect of ash content of the obtained suspension fuel on the amount of fuel supplied at the boiler capacity of $0.58 \mathrm{MW}$ and different solid phase content.

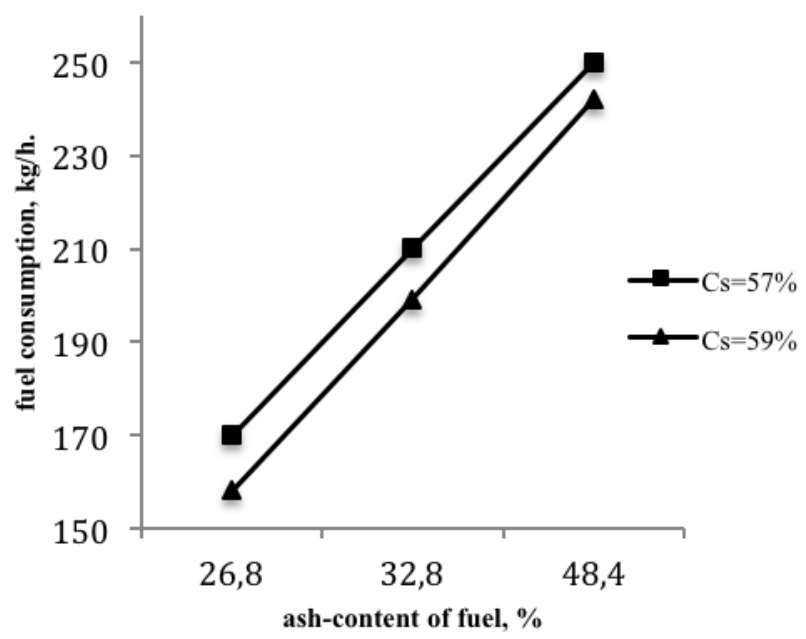

Fig. 2. The influence of ash content fuel on fuel consumption. Solid phase content of 57 and $59 \%$.

The figure shows that an increase in ash content leads to a corresponding increase in the amount of fuel supplied to the combustion while maintaining the heating capacity of the boiler. To analyze the chemical composition, as well as the completeness of the burnup, dust and ash dump were taken from the flue gases and from the grate located at the bottom of the combustion chamber, respectively. All lots of fuel differed little in terms of the magnitude of the underburn - for WCF from FDWCE of CPP coal pit "named after S.M. Kirov" the content of combustible in the underburning (carbon in fly ash) was $-4.8 \%$, and for the fuel of CPP coal pit "Komsomolets" - 4.7\%, i.e. the amount of carbon in fly ash did not exceed $5.0 \%$. Almost complete combustion of the organic mass of coal allows to reduce emissions of harmful substances into the atmosphere and to obtain ash with good characteristics for its use in the construction industry [21].

During the research, gas emissions were measured using the «Testo $300 \mathrm{XXL}$ » gas analyzer. The sampling process for determining the composition and amount of harmful emissions in the flue gases produced during the combustion of fuels was carried out with a stable boiler.

The composition and amount of harmful emissions from combustion of the prepared fuel samples is given in Table 4.

TABLE IV. COMPOZITION AND AMOUNT OF HARMFUL EMISSIONS IN FLUE GASES

\begin{tabular}{|l|c|c|c|}
\hline & $\begin{array}{c}\text { Max } \\
\text { concentration } \\
\text { limit* }\end{array}$ & $\begin{array}{c}\text { WCF } \\
\text { CPP coal pit } \\
\text { «Komsomole } \\
\text { ts» }\end{array}$ & $\begin{array}{c}\text { WCF } \\
\text { CPP coal pit } \\
\text { «named after } \\
\text { S.M. Kirov» }\end{array}$ \\
\hline Dust, mg/m ${ }^{3}$ & 250 & $\begin{array}{c}\text { not more than } \\
170\end{array}$ & $\begin{array}{c}\text { not more than } \\
170\end{array}$ \\
\hline $\mathrm{CO}, \mathrm{mg} / \mathrm{m}^{3}$ & 375 & $\begin{array}{c}\text { not more than } \\
75\end{array}$ & $\begin{array}{c}\text { not more than } \\
75\end{array}$ \\
\hline $\mathrm{NO}_{\mathrm{x}}, \mathrm{mg} / \mathrm{m}^{3}$ & 750 & $\begin{array}{c}\text { not more than } \\
250\end{array}$ & $\begin{array}{c}\text { not more than } \\
230\end{array}$ \\
\hline $\begin{array}{l}\mathrm{SO}, \mathrm{mg} / \mathrm{m}^{3} \\
\text { (a) }\end{array}$ & 1200 & $\begin{array}{c}\text { not more than } \\
200\end{array}$ & $\begin{array}{c}\text { not more than } \\
200\end{array}$ \\
\hline $\begin{array}{l}\text { (benz } \\
\mathrm{pyrene}), \\
\mathrm{mg} / \mathrm{m}^{3}\end{array}$ & $0,1 \cdot 10^{-3}$ & \multicolumn{2}{|c}{$0,1 \cdot 10^{-3}$} \\
\hline
\end{tabular}

a. standards of specific emissions into the atmosphere of particulate matter, carbon monoxide, nitrogen oxides and sulfur, benz (a) pyrene (GOST P50831-95). 
As the data in the table show, the obtained values of harmful emissions are significantly lower than the allowable values for coal boilers of this power when using high-ash fuel.

Thus:

(1) The composition and effect of plasticizing additives on the rheological characteristics of the fuel is defined; the dependence of fuel consumption on its ash content is established.

(2) As a result of the performed work, the technology and equipment for the preparation and combustion of small and medium-power slurry water coal fuel, obtained on the basis of fine-dispersed waste of coal-enrichment (filter cakes) from the CPP coal pits «Komsomolets» and «name after S.M. Kirov». It is shown that on the basis of these wastes it is possible to prepare a suspension water-coal fuel with a solid phase content of $56-59 \%$, with the required structural-rheological characteristics and a net calorific value of up to $13 \mathrm{MJ} / \mathrm{kg}$.

(3) A boiler with a thermal capacity of $0.58 \mathrm{MW}$ with a vortex combustion system, efficiently operating on fuel from coal waste, was developed, manufactured and tested. The results of the operation of the boiler on this fuel showed its high efficiency (the efficiency is $83-85 \%$ ) with the level of harmful emissions in the flue gas significantly below the permissible values. High characteristics were obtained on carbon in fly ash and incomplete combustion levels (correspondingly, not more than $5 \%$ and $80 \mathrm{mg} / \mathrm{m}^{3}$, respectively, which is much less than the allowed values). Thus, the possibility of reducing harmful emissions from the combustion of coal-water fuel from waste coal is shown.

\section{ACKNOWLEDGMENT}

In this paper, the research was sponsored by the JSC SUEK Kuzbass.

\section{REFERENCES}

[1] E.I.Wan, M.D. Fraser, C.N. Logan Low sulphur coal-water fuel to retrofit a coal-fired to comply with US clean air act ammendments of 1990. In: Proceedings og yhe IEA-CLM. Clearwater, FL, USA, (April 1993 ) - Paris, France, International Energy, (1993). p 22.

[2] R.A. Ashworth, T.A. Melick, D.K. Morrison, J.J. Battista Electric utility CWS firing options to reduce $\mathrm{NO}_{\mathrm{x}}$ emissions, Twenty Third International Technical Conference on Coal Utilization and Fuel
Systems, Coal and Slurry Technology Association and ASME-FACT, Clearwater, Florida (1998), pp. 719-730.

[3] J.D. Morrison, A.W. Scaroni, J.J. Battista The use of coal slurries for production of coal-water fuel. XIII International Coal Preparation Congress. Brisbane, Australia (1998). - p. 643-645.

[4] M. Alaa Musalam and Abdel Fattah A. Qaraman. The thermal behavior of the coal-water fuel (CWF). International Journal of Energy and Environmental Research, Vol. 4, No.3, (2016). pp. 27-36.

[5] J. Janiszewski Metrol. and Measur. Sys. 2012. V. 19. No 2. P. 797.

[6] J. Janiszewski Int. J. Solids and Struct. 2012. V. 49. No 7-8. P. 1001.

[7] Murko V.I., Karpenok V.I., Senchurova Yu.A., Khyamyalyainen V.A., Tailakov O.V. Study of sulfur oxide reduction during combustion of coal-water slurry. Coal in the 21st Century: Mining, Processing and Safety (2016). pp. 297-300.

[8] M.P. Baranova, Qian Li, Zhi -Ying Zheng, Feng-Chen Li, V.A. Kulagin, D. Likhachev Utilization slurry coal-water fuel. Journal of Siberian Federal University. Engineering \& Technologies, 7 (2014 4) 474-480.

[9] V.I. Murko, V.I. Fedyaev, V.I. Karpenok, I.M. Zasypkin, Y.A. Senchurova, A. Riesterer Investigation of the spraying mechanism and combustion of the suspended coal fuel. Thermal Science. (2015). T. 19. № 1. pp. 243-251.

[10] V.I. Murko, E.M. Puzyryov, V.I. Karpenok, V.I. Fedyaev, M.P. Baranova The Usage Of Boilers With A Furnace For Burning Enrichment Products And Deballasting Coal / XVIII Internation Coal Preparation Congress, Saint-Petersburg, Russia. - 2016. - P. 345-350.

[11] I. Zasypkin, V. Murko, V. Fedyaev, M. Baranova Systems of ignition and combustion stabilization for water-coal fuel / // J. Thermal Science - Vol. 16. No. 4. 2012. -P. 1329-1338

[12] R.G. Kim, C.H. Jeon Appl. Therm. Eng. 2014. V. 63. No 2. P. 565.

[13] S. Beloševi', I. Tomanovi', V. Beljanski et al. Appl. Therm. Eng. 2015. V. 74. P. 102

[14] V.I. Murko, V.I. Fedyaev, H.L. Aynetdinov, M.P. Baranova Enviromentally clean techology of fine waste coal utilization /The 17th International Coal Preparation Congress. - Turkey. - 2013. - P. 679-682;

[15] Patent No. 2145038. M.cl. F 23 Q 5/00. Method of Combustion and Combustion Stabilization of the Water-Coal Fuel in the Settling Chamber (in Russian). - No. 97120914/06

[16] "Proenergomash" [Electronic resource] URL: www.pem-energo.ru (address date 18.10.2017 г.)

[17] V. Biletskyy, P. Sergeyev and O. Krut Fundamentals of highly loaded coal-water slurries. Mining of Mineral Deposits. Taylor and Francis Group, London (2013). pp. 105-113.

[18] S. P. Mochalov, I. A. Rybenko, L. A. Ermakova Mechanism and Mathematical Modeling of Coal-Water Slurry Combustion in Swirl Adiabatic Combustion Chamber. World Applied Sciences Journal 19 (1) (2012). pp. 20-25.

[19] Kijo-Kleczkowska, A. Combustion of coal-water suspensions, Fuel, 90 (2011) 2, pp. 865-77.

[20] Kijo-Kleczkowska, A. Combustion of coal-water suspensions, Fuel, 90 (2011) 2, pp. 865-77.

[21] Kijo-Kleczkowska, A., Analysis of cyclic combustion of the coalwater suspension Archives of Thermodynamics, 32(1). 2011. pp. 4575 . 